\title{
Fish larvae from the upper Paraná River: Do abiotic factors affect larval density?
}

\author{
Gilmar Baumgartner ${ }^{1}$, Keshiyu Nakatani2 ${ }^{*}$, Luiz Carlos Gomes ${ }^{2}$, Andréa Bialetzki², \\ Paulo Vanderlei Sanches ${ }^{2,3}$ and Maristela Cavicchioli Makrakis ${ }^{1}$
}

The purpose of this study was to evaluate the role of abiotic factors on fish larvae occurrence. Samplings were carried out monthly at 12 stations (grouped in four areas) in the Amambaí, Ivaí and Paraná rivers and in the Itaipu Reservoir (upper Paraná River basin), from October 1994 to January 1995 (spawning season). Simultaneously, we obtained water temperature, pH, electrical conductivity, dissolved oxygen, water level, water velocity, and rainfall. Principal Component Analyses (PCA) and Detrended Correspondence Analyses (DCA) were applied to summarize abiotic and larvae density data, respectively. Amambaí River differed significantly from the other areas in relation to abiotic factors. Itaipu Reservoir differed significantly from the other areas considering species composition, and the Ivaí River also differed from the Paraná River. The relationship among PCA and DCA axes were significant, indicating that abiotic factors do influence larva. For example: Leporinus elongatus prefered the Amambaí River, Hypophthalmus edentatus, Plagioscion squamosissimus, and Hoplias aff. malabaricus the Itaipu Reservoir, and Pimelodus maculatus, Auchenipterus osteomystax and Iheringichthys labrosus the Ivaí River. We suggest that species selected some abiotic factors characteristic to a given environment as spawning grounds.

O objetivo deste trabalho foi avaliar o papel de fatores abióticos na ocorrência de larvas de peixes. As amostragens foram realizadas mensalmente em 12 estações (agrupadas em 4 áreas) nos rios Amambaí, Ivaí e Paraná e no reservatório de Itaipu, de outubro de 1994 a janeiro de 1995 (época de desova). Simultaneamente, foram obtidos dados de temperatura, $\mathrm{pH}$, condutividade elétrica, oxigênio dissolvido, nível da água, velocidade da água e precipitação. Análises de Componentes Principais (PCA) e de Correspondência com Remoção do Efeito de Arco (DCA) foram aplicadas para sumarizar os dados abióticos e as densidades de larvas, respectivamente. O rio Amambaí diferiu significativamente das outras áreas em relação aos fatores abióticos. O reservatório de Itaipu diferiu significativamente das outras áreas quanto à composição de espécies, tendo o rio Ivaí também diferido do rio Paraná neste aspecto. A relação entre os eixos da PCA e DCA foi significativa, indicando que os fatores abióticos influenciam as larvas. Por exemplo, Leporinus elongatus preferiu o rio Amambaí, Hypophthalmus edentatus, Plagioscion squamosissimus e Hoplias aff. malabaricus o reservatório de Itaipu e Pimelodus maculatus, Auchenipterus osteomystax e Iheringichthys labrosus o rio Ivaí. Assim, sugerimos que cada espécie seleciona um conjunto de características abióticas em um dado ambiente utilizado como local de desova.

Key words: Larval ecology, Spatial distribution, Floodplain, Itaipu reservoir, Larval drift.

\section{Introduction}

The reproductive cycle of fish in the tropics are likely determined by several factors such as temperature, rainfall, water level, oxygen availability, electrical conductivity, water $\mathrm{pH}$, alkalinity, nutrients and food availability, and to a lesser extent, the photoperiod (Bye, 1989; Munro, 1990; Vazzoler, 1996). These factors accelerate or slow down the reproductive process and can affect eggs incubation, larval development, growth and survival (Ciechomski, 1966; Korwin-Kossakowski, 1989; Nakatani et al., 2001). Therefore, reproduction of many tropical species is synchronized to environmental seasonality, which guarantees favorable conditions for eggs and larval survival (Baumgartner et al., 1997; Nakatani et al., 1997a; Severi, 1997). Each species requires a unique combination of environmental factors to trigger spawning and determine its reproductive success.

${ }^{1}$ Grupo de Pesquisas em Recursos Pesqueiros e Limnologia - GERPEL - Engenharia de Pesca - Universidade Estadual do Oeste do Paraná (UNIOESTE), rua da Faculdade, 645, Jardim La Salle, 85903-000 Toledo, Paraná, Brazil.(GB) gilmar_baum@yahoo.com.br; (MCM)mcaviccm@hotmail.com ${ }^{2}$ Núcleo de Pesquisas em Limnologia, Ictiologia e Aqüicultura (Nupélia), Departamento de Biologia - Universidade Estadual de Maringá (UEM), Av. Colombo, 5790, bloco H-90, 87020-900 Maringá, Paraná, Brazil. (LCG) lcgomes@nupelia.uem.br; (AB) bialetzki @nupelia.uem.br; ${ }^{3}$ Universidade Paranaense (UNIPAR), Pós-Graduação em Biotecnologia Aplicada a Agricultura, Av. Parigot de Souza, 3636, 85903-170 Toledo, Paraná, Brazil.pvs@unipar.br

*In memoriam 
In the upper Paraná River, information on environmental factors influencing the distribution and abundance of fish larvae is restricted to Baumgartner et al. (1997), Nakatani et al. (1997a, b), Bialetzki et al. (1999, 2002), Castro et al. (2002), and Sanches et al. (2006). However, there is no information on the relationships between environmental factors and fish larvae in the area considered in this study, except those mentioned by Nakatani (1994) for the Itaipu Reservoir.

Thus, the aim of this study was to evaluate the influence of selected abiotic factors on fish larval density. Specifically, we expected to answer the following questions: i) do abiotic factors differ among sampled environments (areas)? ii) does larval species composition differ among environments? and iii) are there any relationships between abiotic factors and larval density?

\section{Material and Methods}

\section{Study Area}

The Paraná River is formed by the confluence of the Paranaíba and the Grande rivers. It flows over $4695 \mathrm{~km}$ in the southern central part of South America and empties in the Plata River (Paiva, 1982) in the border between Uruguay and Argentina. The upper Paraná River (all inside the Brazilian territory, except for the Itaipu Reservoir that borders with Paraguay) has an average slope of $0.18 \mathrm{~m} \mathrm{~km}^{-1}$. There is an extensive floodplain on the west margin that may reach 20 $\mathrm{km}$ wide, between the Porto Primavera Dam and the Itaipu Reservoir, and this stretch corresponds to the last one free of dams of the upper Paraná River within the Brazilian territory.

In the Upper Paraná River $\left(23^{\circ}\right.$ to $25^{\circ} \mathrm{S} ; 53^{\circ}$ to $\left.55^{\circ} \mathrm{W}\right), 12$ stations (grouped in four areas) were sampled; three in the main channel of the Paraná River (Figueira, Morumbi and Saraiva; Paraná area), three in Itaipu Reservoir (Guaçu, Capivara and Ipiranga; Itaipu area), three in the Amambaí River (Areia, Ponte and Bom Fim; Amambaí area), and three in the Ivaí River (Bananeira, Tapira and Pontal do Tigre; Ivaí area) (Fig. 1).

\section{Sampling and data analysis}

Larval samples were taken monthly, from October 1994 to January 1995 (period that corresponds to the spawning season of most species) during $24 \mathrm{~h}$ cycles, with $4 \mathrm{~h}$ intervals between samplings. Conical-cylindrical plankton nets ( $0.5 \mathrm{~mm}$ mesh), with a flowmeter attached to the entrance (to obtain the volume of filtered water) were used to collect larvae. Samples were fixed in buffered $4 \%$ formalin. Abundance (density) of larvae was standardized for a $10 \mathrm{~m}^{3}$ volume of filtered water, modified from Tanaka (1973). Larvae identification was performed according to the developmental sequence technique (Ahlstrom \& Moser, 1976; Nakatani et al., 2001). The specimens analized were deposited in the Icthyoplankton Collection from Nupélia/ UEM and are being incopored to the Ichthyological Collections from Núcleo de Pesquisas em Limnologia, Ictiologia e Aqüicultura (Nupélia/UEM).

Abiotic factors were measured for each sample. Water samples were collected with a Van Dorn bottle and the follow-

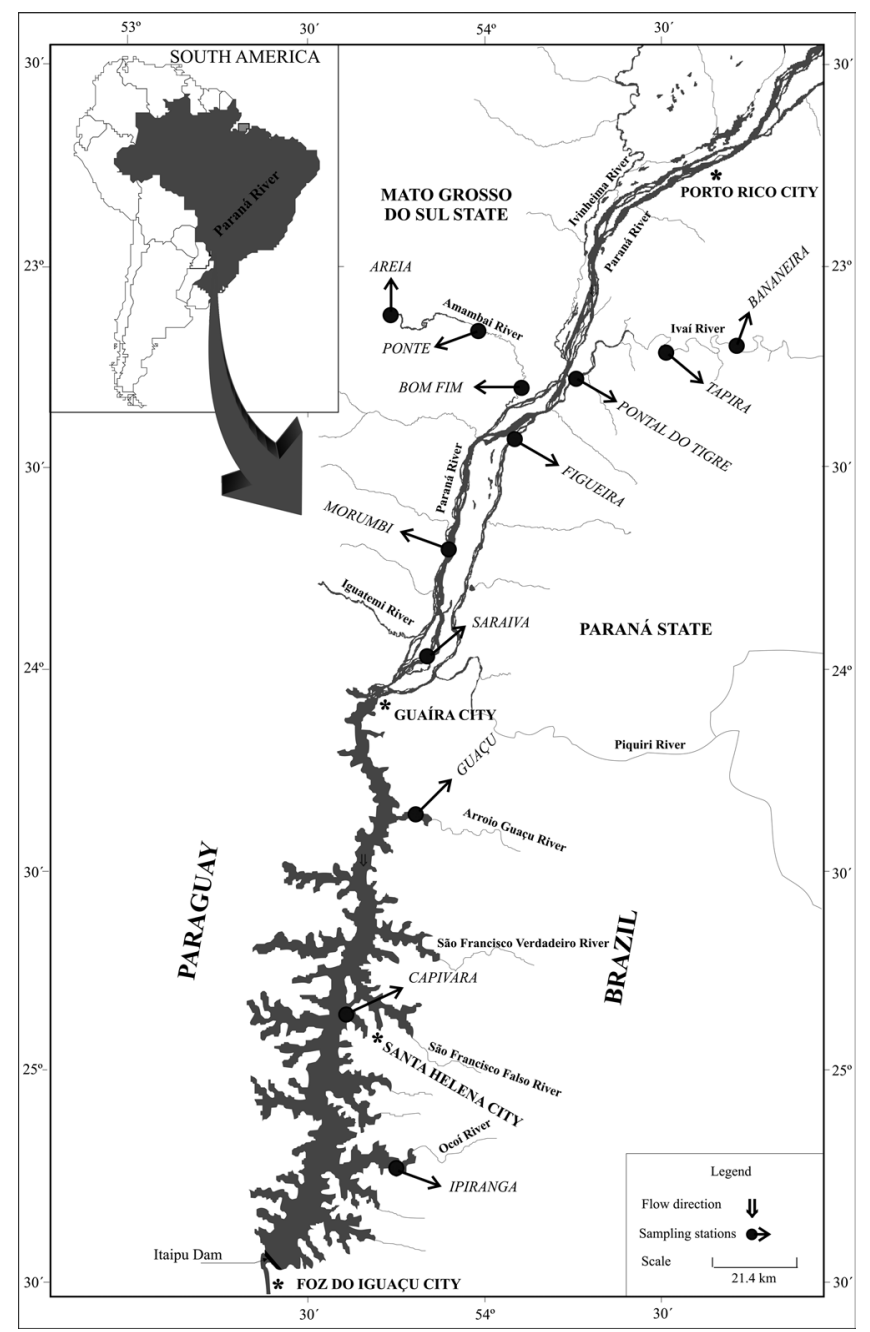

Fig. 1. Map of the upper Paraná River showing the location of the sampling stations.

ing variables were measured: temperature $\left({ }^{\circ} \mathrm{C}\right.$; thermometer), $\mathrm{pH}\left(\mathrm{pH}\right.$ meter), electrical conductivity $\left(\mu \mathrm{S} . \mathrm{cm}^{-1}\right.$; conductivity meter) and dissolved oxygen (mg.L $\mathrm{L}^{-1}$; Winkler's method) (Golterman et al., 1978). Water level (m) and rainfall (mm) for Paraná River (Guaíra), Itaipu Reservoir (Foz do Iguaçu), Amambaí River (Porto Flórida), Ivaí River (Porto Paraíso do Norte) were obtained from the Itaipu Binacional (Hydroeletric power plant). Water velocity $\left(\mathrm{m} . \mathrm{s}^{-1}\right)$ was measured at the subsurface (approximately $20 \mathrm{~cm}$ ) with a flowmeter (General Oceanics $\left.{ }^{\mathrm{TM}}\right)$.

To determine whether abiotic factors differed among sampling areas, we first log transformed environments data $[\log (\mathrm{x}+1)]$ to linearize the relationships and then applied a Principal Component Analyses (PCA). Principal Component axes retained for interpretation were those with eigenvalues larger than 1.0, according to the Kaiser-Guttman's criterion (Jackson, 1993). Abiotic factors with eigenvectors (correlations) larger than 0.40 were considered biologically important (Hair et al., 1984). Analysis of variance (ANOVA) was applied on the scores of the retained axes (that summarized abiotic factors) to assess significant differences among areas. 
To evaluate possible differences in species composition among areas, larval density data were square root transformed to reduce the effect of high densities, and patterns were summarized by Detrended Correspondence Analysis (DCA) (Gauch, 1982). Axes retained for interpretation were those with eigenvalues greater than 0.20 as suggested by Matthews (1998). ANOVA was further applied on the scores of the axes retained for interpretation using areas as factor (ANOVA terminology) to evaluate possible differences in species composition (summarized in the DCA axis). Because DCA is sensitive to rare species (Palmer, 1993), we also used Kendall's Concordance Coefficient (Siegel, 1975) to evaluate consistence in species compositions among areas, considering only the most frequent species.

Afterwards, Pearson's correlation between PCA and DCA axes retained for interpretation was calculated. Significant correlation between axes indicates possible influence of abiotic factors on larval density data matrix (species composition). Parametric tests (ANOVA and Pearson's correlation) and non-parametric (Kendall's Concordance Coefficient) were performed using Statistica ${ }^{\mathrm{TM}}$ (Statsoft, 1999), whereas PCA and DCA were performed using the Pc-Ord (McCune \& Mefford, 1995). Tukey test was applied to determine which area differed whenever ANOVA was significant.

\section{Results}

\section{Abiotic Factors}

In general, mean temperature did not vary greatly among areas, but it was lowest in Amambaí River area, and greatest in Itaipu Reservoir area (Table 1). Mean water $\mathrm{pH}$ was almost neutral, with the lowest value in Amambaí River area and the greatest in Itaipu Reservoir area. Mean electrical conductivity was less than $60 \mu \mathrm{S} . \mathrm{cm}^{-1}$ and was lowest in Amambaí River area and greatest in Ivaí River area. There was little difference in dissolved oxygen among areas, with mean near $7.0 \mathrm{mg} . \mathrm{L}^{-1}$. Mean water velocity was greater in Paraná River area, and slower in Ivaí River area. There was no flow in Itaipu Reservoir area. The highest water level oscillation was detected in Ivaí River area, but there was no variation in Itaipu Reservoir area. Rainfall was high in Itaipu and Paraná areas and low at Ivaí River area.

Two principal components (axes $1-\mathrm{PC} 1$ and 2 - PC2) presented eigenvalues greater than 1.0 and were retained for interpretation (Table 2). These two axes together explained $61.74 \%$ of the data variability (axis 1, 36.52\% and axis 2, $25.22 \%$ ). Electrical conductivity and $\mathrm{pH}$ were positively correlated with this axis, whereas water level was negatively correlated. For instance, temperature and rainfall were positively correlated, whereas water velocity was negatively correlated with PC2.

PC1 clearly ordinated areas (ANOVA; $p<0.05)$, showing that the Amambaí River area differed significantly from the Ivaí River and the Itaipu Reservoir areas (Tukey Test, $p<0.05$ ) (Fig. 2a). PC2 scores also differed significantly according to areas (ANOVA; $\mathrm{p}<0.05$ ), showing that the Amambaí River area differed from the Paraná River and the Itaipu Reservoir areas (Tukey Test, $\mathrm{p}<0.05$ ) (Fig. 2b).

\section{Species composition and density}

During the sampling period, 13,338 larvae were captured (Table 3). Siluriformes (57.2\%) and Characiformes (42.3\%) dominated in abundance, whereas Gymnotiformes, Synbranchiformes, Perciformes, and Pleuronectiformes contributed to a combined $0.5 \%$ of the total abundance. All together, 43 species belonging to 21 families were identified. Characidae (10 species; Characiformes), Anostomidae (5 species; Characiformes), and Pimelodidae and Loricariidae (4 species; Siluriformes) were the families with greater number of species.

The Paraná River area had the largest number of species (37), followed by the Ivaí River and the Itaipu Reservoir (29), and the Amambaí River (17) areas. In the Amambaí River area, Leporinus elongatus, Leporinus friderici, Pimelodus maculatus (all migratory) and Bryconamericus stramineus (no information on life strategy) were the most abundant species. In the Ivaí River area, Pimelodus maculatus (migratory), Auchenipterus osteomystax, Iheringichthys labrosus (non migratory) and Bryconamericus stramineus were the most abundant. In the Itaipu Reservoir area, the greatest density was registered for Нypophthalmus edentatus (non migratory), Pterodoras granulosus (migratory), Bryconamericus stramineus (no information on life strategy) and Iheringichthys labrosus (non migratory). Larvae mentioned on Table 3, such as unidentified Characiformes and Siluriformes, are those whose identification was possible only at the order level due to their preservation state.

Table 1. Mean values $(\bar{x})$ and standard error (se) of abiotic factors (water) for the areas sampled from October 1994 to January 1995.

\begin{tabular}{lcccccccc}
\hline & \multicolumn{2}{c}{ Amambaí } & \multicolumn{2}{c}{ Ivaí } & \multicolumn{2}{c}{ Paraná } & \multicolumn{2}{c}{ Itaipu } \\
\cline { 2 - 9 } & $\bar{x}$ & se & $\bar{x}$ & se & $\bar{x}$ & se & $\bar{x}$ & se \\
\hline Temperature $\left({ }^{\circ} \mathrm{C}\right)$ & 25.7 & 1.27 & 27.2 & 1.57 & 28.3 & 1.46 & 29.5 & 2.16 \\
pH & 6.8 & 0.46 & 7.2 & 0.60 & 7.1 & 0.61 & 7.4 & 0.59 \\
Electrical conductivity & 29.6 & 2.78 & 54.2 & 5.85 & 48.7 & 7.0 & 53.0 & 9.66 \\
$\left(\mu S . c^{-1}\right)$ & & & & & & & & \\
Dissolved oxygen $\left(\mathrm{mg} . \mathrm{L}^{-1}\right)$ & 7.1 & 1.19 & 7.4 & 0.88 & 7.06 & 1.05 & 7.6 & 0.71 \\
Water velocity $\left({\left.\mathrm{m} . \mathrm{s}^{-1}\right)}\right)$ & 0.46 & 0.24 & 0.36 & 0.21 & 0.48 & 0.06 & - & - \\
Water level $(\mathrm{m})$ & 0.24 & 0.27 & 0.65 & 1.36 & 0.14 & 0.49 & - & - \\
Rainfall $(\mathrm{mm})$ & 144.720 .79133 .379 .90179 .690 .70179 .690 .70 \\
\hline
\end{tabular}

Table 2. Results of the Principal Component Analysis (PCA) for the axes retained for interpretation. Eigenvectors (correlations) for each abiotic factors (values greater than 0.4 are in bold; Hair et al., 1984), eigenvalues and percentage of explanation are given.

\begin{tabular}{|c|c|c|}
\hline Variables & $\mathrm{PC} 1$ & $\mathrm{PC} 2$ \\
\hline Temperature $\left({ }^{\circ} \mathrm{C}\right)$ & 0.34 & 0.50 \\
\hline pH & 0.51 & -0.22 \\
\hline Electrical conductivity $\left(\mu S . \mathrm{cm}^{-1}\right)$ & 0.41 & 0.35 \\
\hline Dissolved oxygen $\left(\mathrm{mg} \cdot \mathrm{L}^{-1}\right)$ & 0.20 & 0.15 \\
\hline Water velocity $\left(\mathrm{m}_{\mathrm{s}} \mathrm{s}^{-1}\right)$ & -0.29 & -0.40 \\
\hline Water level (m) & -0.45 & 0.33 \\
\hline Rainfall (mm) & -0.36 & 0.54 \\
\hline Eingenvalues $(\lambda)$ & 2.56 & 1.77 \\
\hline$\%$ of explanation & 36.52 & 25.22 \\
\hline
\end{tabular}


Table 3. Larval species densities (ind. $10 \mathrm{~m}^{-3}$ ) in Amambai River (AMA), Ivaí River (IVA), Paraná River (PAR) and the Itaipu Reservoir (RES), from October 1994 to January 1995 (most abundant species are in bold).

\begin{tabular}{|c|c|c|c|c|c|c|c|c|c|}
\hline Species/areas & AMA & IVA & PAR & RES & Species/areas & AMA & IVA & PAR & RES \\
\hline Characiformes & & & & & Siluriformes & & & & \\
\hline Characidae & & & & & Doradidae & & & & \\
\hline Aphyocharax anisitsi & & & 0.01 & 0.01 & Pterodoras granulosus & & 0.01 & 1.63 & 0.92 \\
\hline Astyanax spp. & & & 0.03 & $<0.01$ & Auchenipteridae & & & & \\
\hline Brycon orbignyanus & & & 0.01 & & Auchenipterus osteomystax & 0.02 & 0.50 & 0.04 & 0.02 \\
\hline Bryconamericus stramineus & 0.05 & 0.12 & 1.56 & 1.51 & Parauchenipterus galeatus & & & $<0.01$ & \\
\hline Characidium sp. & 0.01 & & & & Tatia neivai & 0.01 & & & \\
\hline Hemigrammus marginatus & & & 0.04 & 0.04 & Cetopsidae & & & & \\
\hline Roeboides descalvadensis & & 0.01 & 0.01 & 0.02 & Cetopsis gobioides & & $<0.01$ & 0.02 & \\
\hline Salminus brasiliensis & 0.05 & 0.01 & 0.03 & & Pimelodidae & & & & \\
\hline Serrasalmus spp. & & 0.01 & 0.01 & 0.03 & Iheringichthys labrosus & & 0.33 & 0.04 & 0.14 \\
\hline Moenkhausia intermedia & & & & $<0.01$ & Pimelodus maculatus & 0.07 & 0.63 & 0.32 & 0.11 \\
\hline Anostomidae & & & & & Pseudoplatystoma corruscans & & 0.06 & 0.10 & \\
\hline Leporinus elongatus & 1.41 & 0.01 & 1.27 & 0.05 & Rhamdia quelen & 0.02 & 0.07 & 0.11 & 0.04 \\
\hline Leporinus friderici & 0.09 & 0.01 & 0.30 & 0.02 & Sorubim lima & & 0.01 & 0.10 & 0.03 \\
\hline Leporinus obtusidens & 0.02 & & 0.04 & $<0.01$ & Hypophthalmus edentatus & & & 0.99 & 8.67 \\
\hline Schizodon borellii & & & 0.02 & & Trichomycteridae & & & & \\
\hline Schizodon nasutus & 0.02 & 0.03 & 0.30 & 0.02 & Paravandellia oxyptera & & 0.04 & & \\
\hline Parodontidae & & & & & Callichthydae & & & & \\
\hline Apareiodon affinis & 0.01 & 0.07 & 0.08 & 0.11 & Hoplosternum littorale & & 0.01 & 0.02 & \\
\hline Prochilodontidae & & & & & Loricariidae & & & & \\
\hline Prochilodus lineatus & & 0.02 & $<0.01$ & & Hypostomus sp. & & 0.01 & 0.01 & 0.01 \\
\hline Erythrinidae & & & & & Loricaria sp. & & 0.01 & & \\
\hline Hoplias aff. malabaricus & $<0.01$ & 0.02 & 0.04 & 0.10 & Loricariichthys platymetopon & & $<0.01$ & $<0.01$ & \\
\hline Cynodontidae & & & & & Rhinelepis aspera & & 0.02 & 0.01 & \\
\hline Rhaphiodon vulpinus & & 0.01 & 0.02 & $<0.01$ & unidentified & 0.12 & 1.66 & 2.40 & 1.27 \\
\hline Unidentified & 1.66 & 0.29 & 3.72 & 1.90 & Synbranchiformes & & & & \\
\hline Gymnotiformes & & & & & Synbranchidae & & & & \\
\hline Gymnotidae & & & & & Synbranchus marmoratus & & & & $<0.01$ \\
\hline Gymnotus spp. & 0.01 & 0.01 & 0.02 & 0.01 & Perciformes & & & & \\
\hline Sternopygidae & & & & & Sciaenidae & & & & \\
\hline Eigenmania spp. & 0.01 & & 0.01 & & Plagioscion squamosissimus & & & 0.06 & 0.03 \\
\hline Apteronotidae & & & & & Cichlidae & & & & \\
\hline \multirow[t]{4}{*}{ Apteronotus albifrons } & & 0.01 & & & Crenicichla britskii & & & & $<0.01$ \\
\hline & & & & & Pleuronectiformes & & & & \\
\hline & & & & & Achiridae & & & & \\
\hline & & & & & Catathyridium jenynsii & & & 0.01 & 0.02 \\
\hline
\end{tabular}

Detrended Correspondence Analysis (DCA) showed that only two axes (DCA1, eigenvalue $=0.80 ;$ DCA2, eigenvalue $=$ 0.53 ) presented eigenvalues higher than 0.20 . ANOVA applied on the scores showed that areas differed significantly on DC1 $(\mathrm{p}<0.05)$ indicating that larval composition in the reservoir differed significantly (Tukey Test; $\mathrm{p}<0.05$ ) from the others (Fig. $3 a)$. DC2 also ordinated significantly by the areas $(p<0.05)$, showing that larval composition in the Ivaí River area was different from those in the Paraná River and the Itaipu Reservoir $(p<0.05)$ areas (Fig. 3b). Kendall's Concordance Coefficient showed a low agreement $(r=0.26 ; p<0.05)$ in the ranks of the 10 main species captured in the different areas, supporting the idea that the areas presented different species compositions and were not affected by the rare species recorded.

\section{Influence of abiotic factors in density}

Pearson's Correlation between PC1 and DC1 was significant $(\mathrm{r}=0.40 ; \mathrm{p}<0.05)$. Then, the abundance of $H$. edentatus, $P$. squamosissimus and $H$. aff. malabaricus (species with the most positive scores on DC1) were positively associated with higher values of $\mathrm{pH}$ and electrical conductivity, especially in the Itaipu Reservoir area, and diminished in places with higher water level (Amambaí and Ivaí River areas). In contrast,
L. elongatus densities (the lowest score on this axis) were associated with higher water level and lower $\mathrm{pH}$ and electrical conductivity (Amambaí River area) (Fig. 4a).

The first DCA axis also correlated significantly $(\mathrm{r}=0.43$; $\mathrm{p}<0.05$ ) with PCA axis 2 , showing that $H$. edentatus, P. squamosissimus and $H$. aff. malabaricus densities were higher where water temperature and rainfall increased, and water velocity decreased (Reservoir), the opposite occurred for $L$. elongatus (Fig. 4b).

The second DCA axis and the first PCA axis were also correlated ( $\mathrm{r}=0.36 ; \mathrm{p}<0.05)$, and $P$. maculatus, A. osteomystax and I. labrosus larvae (species with the most positive scores in DCA second axis) densities were associated with diminished water level, elevated water $\mathrm{pH}$ and electrical conductivity (Ivaí River area). However, P. granulosus, S. nasutus and $L$. friderici densities (most negative scores on this axis) were associated with increased water level and decreased water $\mathrm{pH}$, and electrical conductivity (Paraná River area) (Fig. 5a).

Correlation between DCA and PCA second axis was negative $(\mathrm{r}=-0.38 ; \mathrm{p}<0.05)$. Then, P. maculatus, A. osteomystax and $I$. labrosus were captured in areas with low temperature and rainfall, and high water velocity (Ivaí River area). However, P. granulosus, S. nasutus and L. friderici larvae occurred 


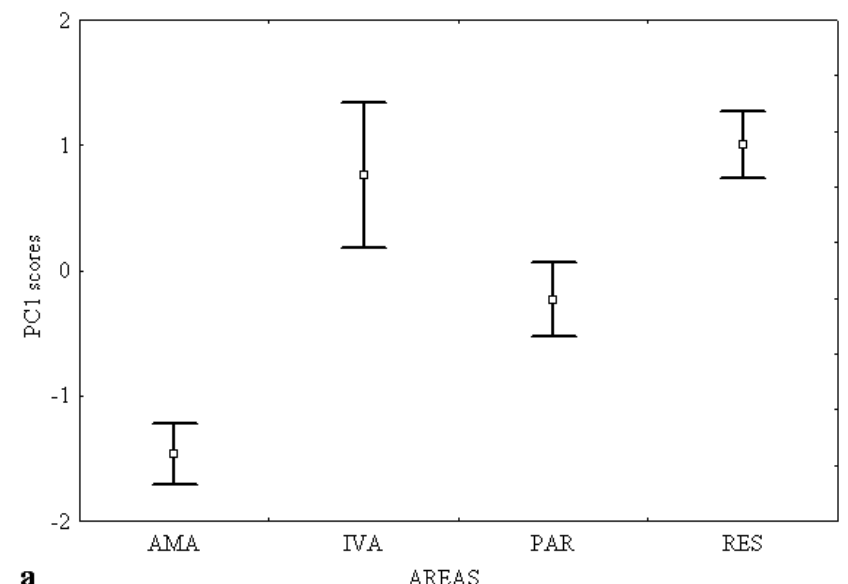

a

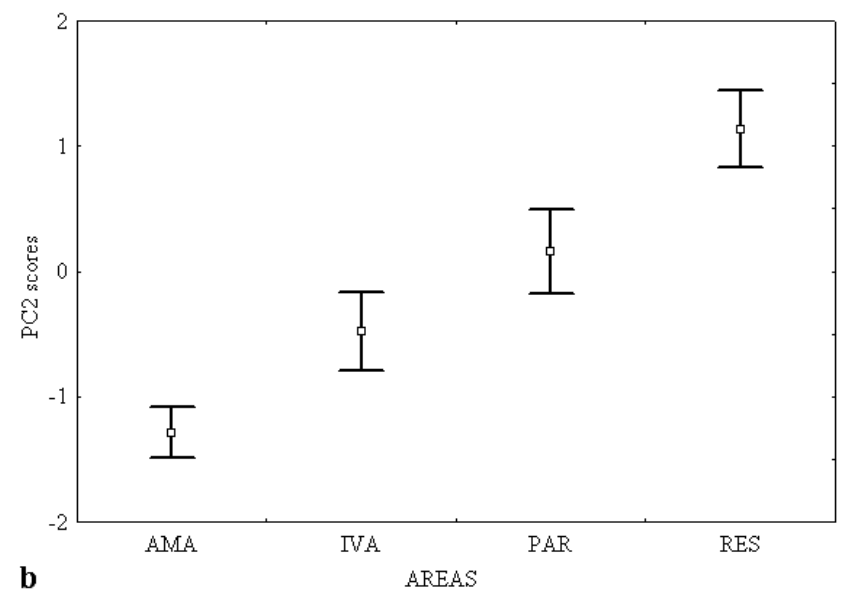

Fig. 2. Mean scores (rectangles) and standard error (bars) $(\mathrm{a}=\mathrm{PC} 1$ and $\mathrm{b}=\mathrm{PC} 2)$ for the different areas, derived from the abiotic factors matrix $(\mathrm{AMA}=\mathrm{Amambai}$ River, $\mathrm{IVA}=$ Ivaí River, PAR= Paraná River and RES= Itaipu Reservoir).

more in environments with elevated temperature and rainfall and diminished water velocity (Paraná River and Itaipu Reservoir areas) (Fig. 5b).

\section{Discussion}

Differences in measured abiotic factors between the Amambaí River and the other areas appear to be a result of the basin characteristics, such as the presence of sandy soil, riparian vegetation, natural barriers, under water vegetation and suspended substances. Differences in abiotic factors among environments in the upper Paraná River floodplain were verified by Thomaz et al. (1997).

In spite of the great difficulty to identify fish larvae, the number of species reported in this study corresponds to $25 \%$ of the species mentioned by Agostinho \& Zalewski (1996) and was greater than that found by Nakatani et al. (1997a) and by Baumgartner et al. (1997) in the floodplain of this same river. The high densities of Siluriformes in this study differs from results reported by Araújo-Lima \& Oliveira (1998) in the Amazon region, in the upper Paraná River floodplain reported by Baumgartner et al. (1997), and in the Mato Grosso Pantanal
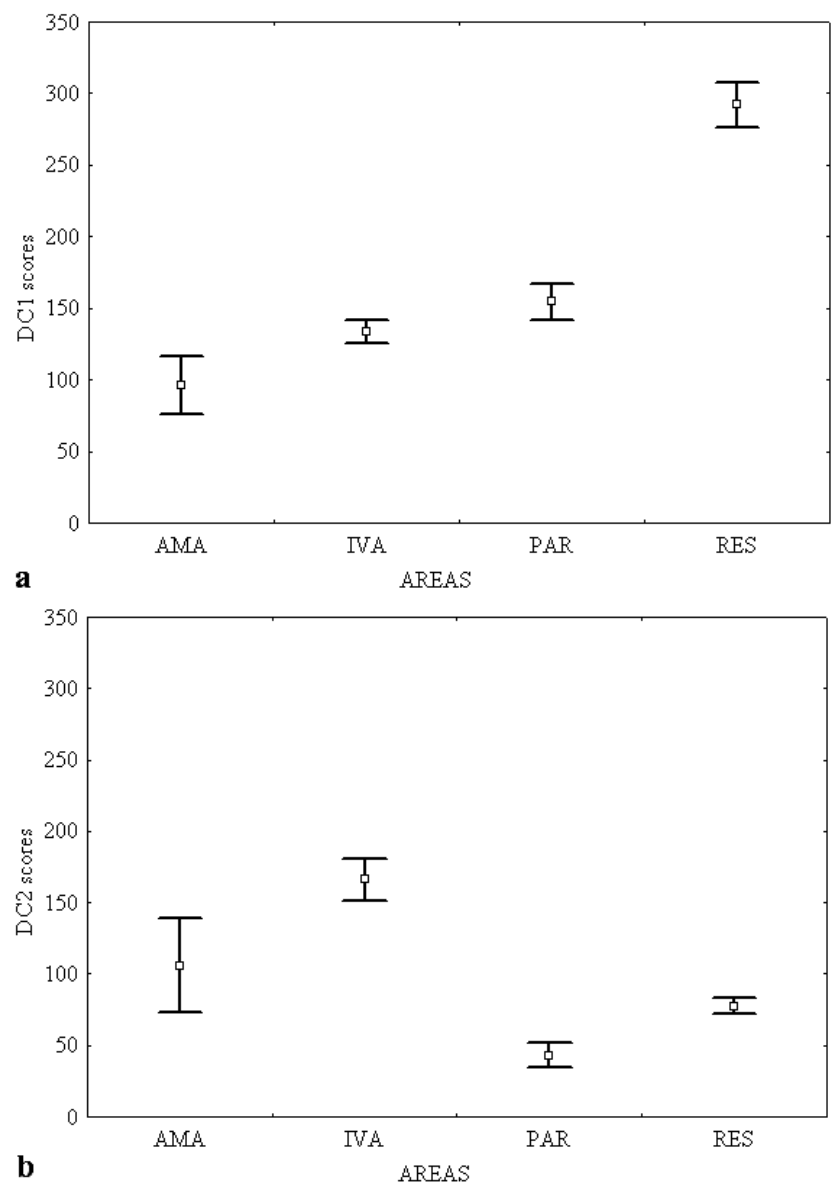

Fig. 3. Mean scores (rectangles) and standard error (bars) (Axis $1=\mathrm{a}$ and Axis $2=\mathrm{b}$ of the Detrended Correspondence Analysis; DCA), derived from the larva density matrix for the different areas $(\mathrm{AMA}=$ Amambaí River, IVA= Ivaí River, $\mathrm{PAR}=$ Paraná River and RES= Itaipu Reservoir).

reported by Severi (1997). In these places, Characiformes dominated the catch. In the upper Paraná River floodplain, Characiformes and Siluriformes dominance over the other orders is also reported by Agostinho et al. (1997). High densities of $H$. edentatus, $P$. granulosus and $P$. maculatus larvae explain the largest capture of Siluriformes, especially in the Itaipu Reservoir and Ivaí River areas.

The presence of larvae of migratory and non-migratory species in the studied area indicates that it is fundamental for the preservation of the upper Paraná River basin ichthyofauna. Presence of larvae of migratory species in other regions of this basin has been documented by Nakatani et al. (1997a) in the Baia, Ivinhema, and Paraná rivers.

The lentic nature of the reservoir justifies the expressive difference in the specific composition from other areas. Baumgartner et al. (2004) reported that in Itaipu Reservoir the ichthyoplankton is mainly composed of non-migratory species, whereas in the Amambaí and Paraná areas migratory species are dominant.

Leporinus elongatus, P. maculatus, P. granulosus and L. friderici larvae occurrence in lotic environments and $H$. 

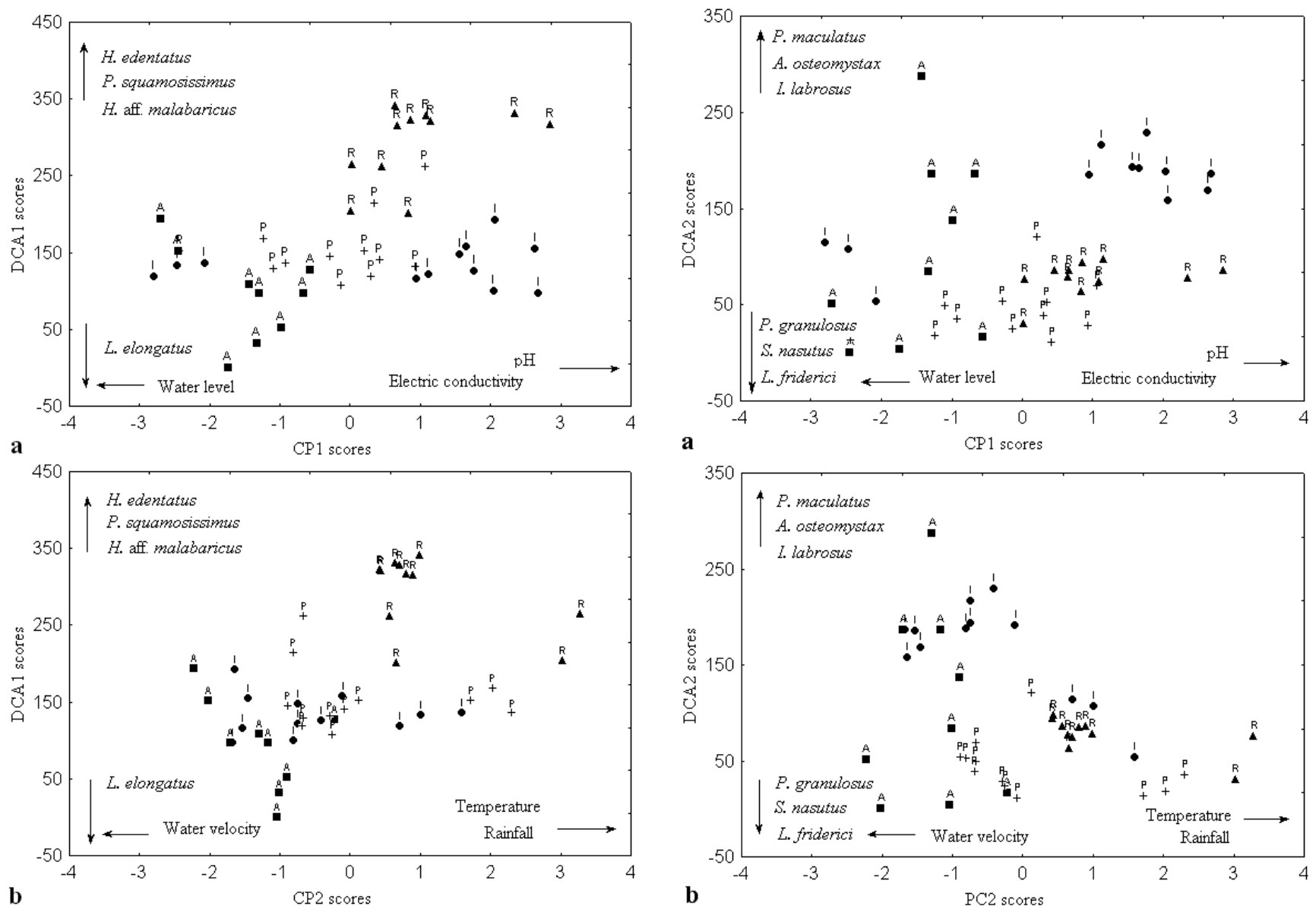

Fig. 4. Scatterplot between the first Detrended Correspondence Analysis axis (DCA1) scores and the Principal Components [PC1 (a) and PC2 (b)] retained for interpretation. $(\mathrm{A}=$ Amambaí River, $\mathrm{I}=$ Ivaí River, $\mathrm{P}=$ Paraná River and $\mathrm{R}=$ Itaipu Reservoir).

edentatus, $P$. squamosissimus and $H$. aff. malabaricus in lentic environments is associated with their reproductive strategies. Leporinus elongatus, P. maculatus, P. granulosus and $L$. friderici are migratory but $H$. edentatus, $P$. squamosissimus and $H$. aff. malabaricus are not (Vazzoler, 1996; Agostinho et al., 2003).

Water temperature is one of the most important factors in fishes life cycle. It can speed up or delay metabolic processes. The relationship between $H$. edentatus, $P$. squamosissimus, $H$. aff. malabaricus, P. granulosus, S. nasutus and L. friderici larval occurrence and high temperatures was also documented in other environments in the Paraná River by several authors (Baumgartner, 1992; Baumgartner et al., 1997; Cavicchioli et al., 1997; Bialetzki et al., 2002). The greatest reproductive intensity of most fish species in the upper Paraná River occurs between October and February (Vazzoler, 1996), when water temperatures are highest.

The preference of some species for slightly acid water $\mathrm{pH}$ and low electrical conductivity, as for L. elongatus, seems to be a behavior adopted by some species in certain regions of Brazil. Dei Tós et al. (2002) observed more intense reproduc-

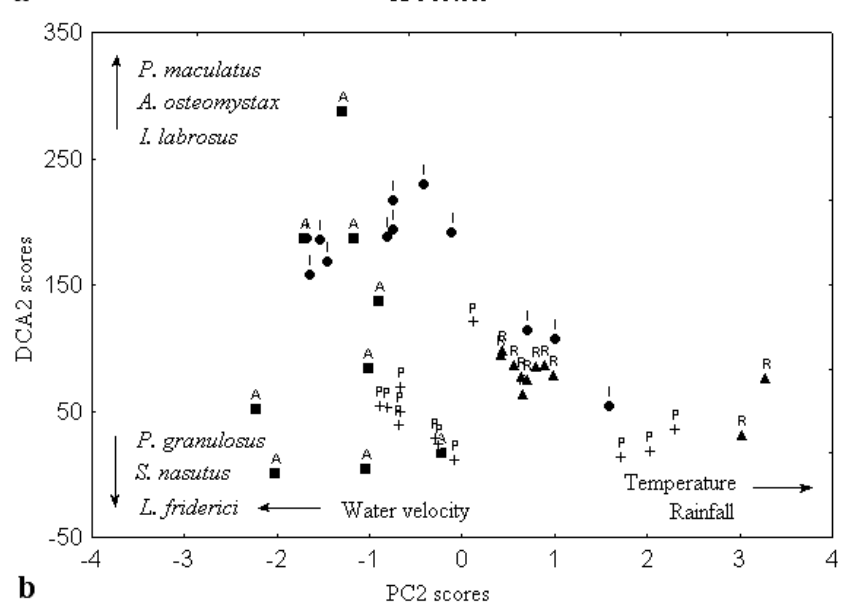

Fig. 5. Scatterplot between the second Detrended Correspondence Analysis axis (DCA2) scores and the principal components [PC1 (a) and PC2 (b)] retained for interpretation. ( $\mathrm{A}=$ Amambaí River, I=Ivaí River, $\mathrm{P}=$ Paraná River and $\mathrm{R}=$ Itaipu Reservoir).

tive activity by P. maculatus in the Corumbá Reservoir when water $\mathrm{pH}$ was slightly acid. On the other hand, Baumgartner et al. (1997) reported that for some species, larval density was positively correlated with water $\mathrm{pH}$. The same is reported for species like H. edentatus, $P$. squamosissimus, $H$. aff. malabaricus, P. maculatus, A. osteomystax, and I. labrosus in this study. Although it is not clear how $\mathrm{pH}$ and electrical conductivity affect the reproductive process, in some manner they induce spawning for some species.

Water level is the main factor acting on tropical fish communities (Lowe-McConnell, 1987; Junk et al., 1989; Vazzoler, 1996) and it can affect species composition (Agostinho et al., 1997). When water level was high, we observed the greatest larval densities for P. maculatus, A. osteomystax and I. labrosus. Similar results were reported by Araújo-Lima (1984) for the Amazon-Solimões River, by Severi (1997) in the Mato Grosso Pantanal, and by Baumgartner et al. (1997) and Bialetzki et al. (2002), in the upper Paraná River floodplain. In some regions, water level increase is the only way for larvae of some species to reach lagoons that do not have connection with rivers. 
Rainfall, in addition to temperature and water level can act in aquatic environments promoting alterations in limnological characteristics, which in turn can affect organisms. Relationships between rainfall and larvae occurrence were observed for $H$. edentatus, $P$. squamosissimus, $H$. aff. malabaricus, $P$. granulosus, $S$. nasutus and $L$. friderici, and were also reported by Baumgartner (1992) for P. squamosissimus, and by Castro (2002) for some species in the upper Paraná River floodplain. Relationships of larvae density and environmental conditions observed in this study strengthen Vazzoler's (1996) statement that environment condition variations are closely connected to each species reproductive strategies throughout its life cycle.

Based on the results of this study we can conclude that at least some fish species of the upper Paraná River migrate upstream towards tributaries to spawn. Abiotic factors may trigger and prolong spawning and provide favorable conditions for larval development (Fig. 6). The last stretch free of dams of the upper Paraná River inside the Brazilian territory is, therefore, fundamental to maintain regional biodiversity and fisheries.

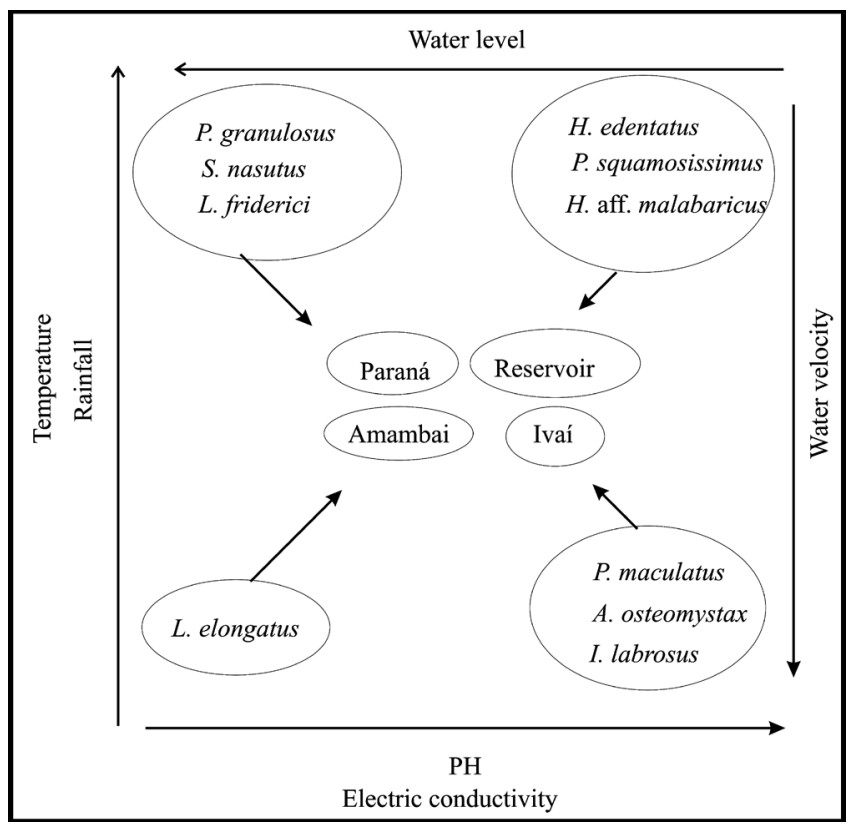

Fig. 6. Conceptual model showing the relationships among abiotic factors, species larvae and areas (arrow directions on axis show increasing values of abiotic factors).

\section{Acknowledgements}

We thanks the Núcleo de Pesquisas em Ictiologia, Limnologia e Aqüicultura (Nupélia) for the logistic support during samplings, Itaipu Binacional for financial support, and the Pós-Graduação em Ecologia de Ambientes Aquáticos Continentais (PEA) for the opportunity. The Conselho Nacional de Desenvolvimento Científico e Tecnológico $(\mathrm{CNPq})$ provided grants for $\mathrm{GB}$ and $\mathrm{LCG}$.

\section{Literature Cited}

Agostinho, A. A., L. C. Gomes, H. I. Suzuki \& H. F. Júlio Jr. 2003. Migratory fishes of the upper Paraná River Basin, Brazil. Pp. 19-98. In: Carolsfeld, J., B. Harvey, C. Ross, \& A. Baer (Eds.). Migratory fishes of South America: biology, fisheries and conservation status. British Columbia, Canada, World Fisheries Trust, $380 \mathrm{p}$.

Agostinho, A. A., H. F. Júlio Jr., L. C. Gomes, L. M. Bini \& C. S. Agostinho. 1997. Composição, abundância e distribuição espaçotemporal da ictiofauna. Pp. 179-208. In: Vazzoler, A. E. A. M., A. A. Agostinho \& N. S. Hahn (Eds.). A planície de inundação do alto rio Paraná. aspectos físicos, biológicos e socioeconômicos. Maringá, EDUEM, 460 p.

Agostinho, A. A., A. E. A. M. Vazzoler \& S. M. Thomaz. 1995. The high Paraná river basin: limnological and ichthyological aspects. Pp. 59-103. In: Tundisi, J. G., C. E. M. Bicudo \& T. MatsumuraTundisi (Eds.). Limnology in Brazil. Rio de Janeiro, Brazilian Academy of Science/Brazilian Limnological Society, 376p.

Agostinho, A. A. \& M. Zalewski. 1996. A planície alagável do alto rio Paraná: importância e conservação. Maringá, EDUEM, 100p.

Ahlstrom, E. H. \& H. G. Moser. 1976. Eggs and larva of fishes and their role in systematic investigations and in fisheries. Revue des Travaux I'Institut des Peches Maritimes, 40:378-398.

Araújo-Lima, C. A. R. M. 1984. Distribuição espacial e temporal de larvas de Characiformes em um setor do rio Solimões/Amazonas, próximo a Manaus. Unpublished Ph.D. Dissertation, INPA/FUA, Manaus, 86p.

Araújo-Lima C.A. R. M. \& E. C. Oliveira. 1998. Transport of larval fish in the Amazon. Journal of Fish Biology, 53:297-306.

Baumgartner, M. S. T. 1992. Distribuição espacial e temporal de larvas de curvina, Plagioscion squamosissimus, (Heckel, 1840) (Osteichthyes, Perciformes) na planície de inundação do alto rio Paraná-MS. Unpublished Monograph, Universidade Estadual de Maringá, Maringá, 36p.

Baumgartner, M. S. T., K. Nakatani, G. Baumgartner \& M. C. Makrakis. 2003. Spatial and temporal distribution of 'curvina' larva (Plagioscion squamosissimus Heckel, 1840) and its relationship to some environmental variables in the upper Paraná River floodplain, Brazil. Brazilian Journal of Biology, 63:381-391.

Baumgartner, G., K. Nakatani, M. Cavicchioli \& M. S. T. Baumgartner. 1997. Some aspects of the ecology of fish larva in the floodplain of high Paraná River, Brazil. Revista Brasileira de Zoologia, 14:551-563.

Baumgartner, G., K. Nakatani, L. C. Gomes, A. Bialetzki, P. V. Sanches \& M. C. Makrakis. 2004. Identification of spawning sites and natural nurseries in the upper Paraná River, Brazil. Environmental Biology of Fishes, 71:115-125.

Benedito-Cecílio, E. \& A. A. Agostinho. 1991. Biologia reprodutiva de Hypophthalmus edentatus (Spix, 1829) (Osteichthyes, Siluriformes) no reservatório de Itaipu-Paraná. I. Estrutura dos ovários e escala de maturidade. Revista Unimar, 13:211-227.

Bialetzki, A., P. V. Sanches, M. Cavicchioli, G. Baumgartner, R. P. Ribeiro \& K. Nakatani. 1999. Drift of ichthyoplankton in two channels of the Paraná River, between Paraná and Mato Grosso do Sul States, Brazil. Brazilian Archives of Biology and Technology, 42:53-60.

Bialetzki, A., K. Nakatani, P. V. Sanches \& G. Baumgartner. 2002. Spatial and temporal distribution of larva and juveniles of $\mathrm{Ho}-$ plias aff. malabaricus (Characiformes, Erythrinidae) in the upper Paraná River floodplain, Brazil. Brazilian Journal of Biology, 62:211-222. 
Bye, V. J. 1989. The role of environmental factors in the timing of reproductive cycles. Pp 187-205. In: Potts, G. W. \& R. J. Wootton (Eds.). Fish reproduction: strategies and tatics. London, Academic Press, 410p.

Castro, R.J., K. Nakatani, A. Bialetzki, P. V. Sanches \& G. Baumgartner. 2002. Temporal distribution and composition of the ichthyoplankton from Leopoldo's Inlet on the upper Paraná River floodplain (Brazil). Journal of Zoology, 256:437-443.

Cavicchioli, M., K. Nakatani \& O. A. Shibatta. 1997. Morphometric variation of larva and juveniles of the piranhas Serrasalmus spilopleura and S. marginatus (Characidae: Serrasalminae) of the Paraná basin, Brazil. Ichthyological exploration of freshwaters, 8:97-106.

Ciechomski, J. D. 1966. Influence of some environmental factors upon the embryonic development of the argentine anchovy Engraulis anchoita (Hubbs, Marini). California Cooperative Oceanic Fisheries Investigations, 11:67-71.

Claramunt, R. M. \& D. H. Wahl. 2000. The effects of abiotic and biotic factors in determining larval fish growth rates: a comparison across species and reservoirs. Transactions of the American Fisheries Society, 129:835-851.

Dei Tós, C. D., G. Barbieri, A. A. Agostinho, L. C. Gomes \& H. I. Suzuki. 2002. Ecology of Pimelodus maculatus (Siluriformes) in the Corumbá Reservoir, Brazil. Cybium, 26:275-282.

Gauch, Jr H. G. 1982. Multivariate analysis in community ecology. Cambridge, Cambridge University Press, 298p.

Golterman, H., R. S. Clymo \& M. A. A. Ohmstad. 1978. Methods for physical and chemical analysis of freshwaters. Oxford, Blackwell Scientific Publication, 214p.

Hair, J. F., R. E. Anderson, L. Tatham \& B. J. Grablowski. 1984. Multivariate data analysis. New York, McMillan, 360p.

Jackson, D. A. 1993. Stopping rules in principal components analysis: a comparison of heuristical and statistical approaches. Ecology, 74:2204-2214.

Johnston, T. A., M. N. Gaboury, R. A. Janusz \& L. R. Janusz. 1995. Larval drift in the Valley River, Manitoba: influence of abiotic and biotic factors, and relationships with future year-class strengths. Canadian Journal Aquatic Science, 52:2423-2431.

Junk, W. J., P. B. Bayley \& R. E. Sparks. 1989. The flood pulse concept in river-floodplain systems. Canadian Special Publication of Fisheries Aquatic Sciences, 106:110-127.

Korwin-Kossakowski, M. 1989. Larval development of carp, Cyprinus carpio L., in acidic water. Journal of Fish Biology, 32:17-26.

Lowe-McConnell, R. H. 1987. Ecological studies in tropical fish communities. Cambridge, Cambridge University Press, 387p.

Matthews, W. J. 1998. Patterns in freshwater fish ecology. New York, Chapman \& Hall, 756p.

McCune, B. \& C. Mefford. 1995. PC-ORD. Multivariate analysis of ecological data, version 2.0. Oregon, MJM Software Design, $126 \mathrm{p}$.

Munro, A. D. 1990. General introduction. Pp. 1-11. In: Munro A. D., A. P. Scott \& Lam T. J. (Eds.) Reproductive seasonality in teleosts: environmental influences. Flórida, CRC Press, 254p.
Nakatani, K. 1994. Estudo do ictioplâncton no reservatório de Itaipu (rio Paraná-Brasil): levantamento das áreas de desova. Unpublished Ph.D. Dissertation, Universidade Federal do Paraná, Curitiba. 253p.

Nakatani, K., A. A. Agostinho, G. Baumgartner, A. Bialetzki, P. V. Sanches, M. C. Makrakis \& C. S. Pavanelli. 2001. Ovos e larvas de peixes de água doce: desenvolvimento e manual de identificação. Maringá, EDUEM, 349p.

Nakatani, K., G. Baumgartner \& M. S. T. Baumgartner. 1997b. Larval development of Plagioscion squamosissimus (Heckel) (Perciformes, Sciaenidae) of Itaipu reservoir (Paraná River, Brazil). Revista Brasileira de Zoologia, 14:35-44.

Nakatani, K., G. Baumgartner \& M. Cavicchioli. 1997a. Ecologia de ovos e larvas de peixes. Pp. 281-306. In: Vazzoler, A. E. A. M., A. A. Agostinho \& N. S. Hahn (Eds.) A planície de inundação do alto rio Paraná. aspectos físicos, biológicos e socioeconômicos. Maringá, EDUEM, 460p.

Paiva, M. P. 1982. Grandes represas do Brasil. Brasília, Editerra, 292p.

Palmer, M. W. 1990. The estimation of species richness by extrapolation. Ecology, 71:1195-1198.

Peters, R. K. 1986. The role of prediction in limnology. Limnology and Oceanography, 31:1143-1159.

Sanches, P. V., K. Nakatani, A. Bialetzki, G. Baumgartner, L. C. Gomes \& E. A. Luiz. 2006. Flow regulation by dams affecting ichthyoplankton: the case of the Porto Primavera dam, Paraná River, Brazil. River Research and Applications, 22:555-565.

Severi, W. 1997. Ecologia do ictioplâncton no pantanal de Barão de Melgaço, bacia do rio Cuiabá, Mato Grosso, Brasil. Unpublished, Ph.D. dissertation, Universidade Federal de São Carlos, São Carlos. 264p.

Siegel, S. 1975. Estatística não-paramétrica: para ciências do comportamento. São Paulo, McGraw-Hill, 350p.

Statsoft. 1999. Statistica ('99 edition): quick reference. Tulsa, StatSoft.

Tanaka, S. 1973. Stock assessment by means of ichthyoplankton surveys. FAO Fisheries Technical Paper, 122:33-51.

Thomaz, S. M., M. C. Roberto \& L. M. Bini. 1997. Caracterização limnológica dos ambientes aquáticos e influência dos níveis fluviométricos. Pp. 73-102. In: Vazzoler, A. E. A. M., A. A. Agostinho \& N. S. Hahn (Eds.). A planície de inundação do alto rio Paraná. aspectos físicos, biológicos e socioeconômicos. Maringá, EDUEM, 460p.

Uphoff Jr., J. H. 1988. Environmental effects on survival of eggs, larva, and juveniles of striped bass in the Choptank River, Maryland. Transaction of the American Fisheries Society, 118:251-263.

Vazzoler, A. E. A. M. 1996. Biologia da reprodução de peixes teleósteos: teoria e prática. Maringá, EDUEM, 169p.

Welcomme, R. L. 1979. Fisheries ecology of floodplain rivers. London, Longman, 317 p.

Accepted May 2008 Published December 22, 2008 